\title{
Stock Options and Credit Default Swaps in Risk Management
}

\author{
Bassam Al-Own \\ Faculty of Finance and Business Administration \\ Al al-Bayt University \\ Mafraq 25113, Jordan \\ Email: bown@aabu.ed.jo \\ Marizah Minhat* \\ The Business School \\ Edinburgh Napier University \\ Edinburgh EH14 1DJ, United Kingdom \\ Email:m.minhat@napier.ac.uk \\ Simon Gao \\ The Business School \\ Edinburgh Napier University \\ Edinburgh EH14 1DJ, United Kingdom \\ Email: S.Gao@napier.ac.uk
}

Journal of International Financial Markets, Institutions and Money (forthcoming)

\footnotetext{
* Corresponding author.

Acknowledgement: This paper was presented at the 2016 Cross Country Perspectives of Finance conferences held in Taiyuan and Pu'er, China. The authors would like to thank Professor Gady Jacoby, Professor Zhenyu Wu, anonymous reviewers, and the conferences' participants.
} 


\title{
Stock Options and Credit Default Swaps in Risk
}

\section{Management}

\begin{abstract}
The use of stock options and credit default swaps (CDS) in banks is not uncommon. Stock options can induce risk-taking incentives, while CDS can be used to hedge against credit risk. Building on the existing literature on executive compensation and risk management, our study contributes novel empirical support for the role of stock options in restraining the use of CDS for hedging purposes. Based on data of CEO stock options and CDS held by 60 European banks during the period 2006-2011, we find a negative relationship between option-induced risktaking incentives (vega) and the proportion of CDS held for hedging. However, the extent of CDS held for hedging is found to be positively related to default risk in the period leading to the financial crisis that erupted in 2007. The findings imply that restraining the use of stock options can incentivize hedging with CDS, but this risk management strategy will not necessarily produce lower default risk in times of systemic credit crisis.
\end{abstract}

Key words: Stock Options; Credit Default Swaps; Risk Management; Vega; Bank Risktaking; Credit Crisis

JEL classification: G21, G32, J33 


\section{INTRODUCTION}

Studies on corporate risk management and derivatives use commonly view derivatives as hedging instruments (e.g., Smith and Stulz, 1985; Rogers, 2002; Aretz and Bartram, 2010). The role of credit derivatives as credit risk management instruments in banks is widely acknowledged (e.g., Hirtle, 2009; Nijskens and Wagner, 2011). Banks have dominated the credit derivatives market, in which CDS are the most commonly used credit derivatives globally (British Bankers’ Association (BBA), 2006; Minton et al., 2009; International Swaps and Derivatives Association (ISDA), 2010). However, the incentives underlying the use of CDS and the effectiveness of such credit risk management remain unknown (Minton et al., 2009). Our study contributes to filling this gap.

CDS allow the transfer of credit risk across firms, whereby buying CDS allows a bank to short exposure to credit risk at a known cost (i.e., insurance premium). From the buyer's perspective, the economic effect of a CDS contract is similar to that of an insurance contract, because it protects the buyer against the default of the underlying asset during the life of the contract (Duffee and Zhou, 2001). This protection is important for banks that are constantly exposed to the credit or default risks of risky assets (e.g., loans and mortgages). We can expect that banks with hedging motives or those managed by risk-averse managers are more likely to buy CDS that transfer the credit risks of risky assets to the sellers of such derivatives.

However, bank managers are not always risk-averse, because their risk-taking appetites would enhance when stock options are included in their pay packages. Studies on executive compensation suggest that equity-based pay, such as stock options, had induced risk-taking behaviours among bank managers in the build-up of the 2007-2008 crisis (e.g., Bebchuk et al., 2010; Fortin et al., 2010; Minhat and Abdullah, 2016). Some studies also suggest that stock options can discourage managers from hedging risk (e.g., Smith and Stulz, 1985; Tufano, 1996; Rajgopal and Shevlin, 2002; Aretz and Bartram, 2010; Bakke et al., 2016). This is because 
stock options contain an important feature that can induce, rather than restrain, managers' risktaking appetites. This feature is described as vega, which measures the extent of risk-taking incentives induced by stock options (Guay, 1999; Rogers, 2002; Coles et al., 2006; Minhat and Abdullah, 2016).

Vega is the measurement of a stock option's sensitivity to the volatility (or risk) of the underlying stock. Because the value of a stock option is positively related to the volatility of the underlying stock, the presence of vega will discourage managers from hedging against risk or volatility (e.g., Rajgopal and Shevlin, 2002; Aretz and Bartram, 2010). If hedging against credit risk can reduce a bank's stock volatility (Nijskens and Wagner, 2011), then that risk management strategy is not in the best interest of managers who wish to increase the value of their stock options. Therefore, we conjecture that vega will provide bank managers with little incentive to buy CDS for hedging purposes.

Our study contributes novel empirical evidence in support of the hypothesis that vega of stock options can disincentivize the use of CDS for risk management in banks. To our knowledge, this hypothesis has not been tested elsewhere. In this study, data of CEO stock options and the notional amount of CDS held for hedging by European banks during the period 2006-2011 were examined. We find that CEO vega is negatively related to the proportion of CDS held for hedging, which is consistent with our hypothesis.

However, the effect of such hedging activity is understandably beyond managerial control. In a further analysis, we find that the extent of CDS held for hedging is positively related to default risk in the period leading to the financial crisis that erupted in 2007. This finding suggests that banks' default risk increases in times of systemic credit crisis even for banks with hedging positions in CDS. We refer to insights offered by previous studies (Stulz, 2010; Nijskens and Wagner, 2011; Fung et al., 2012) to rationalise this interesting observation. Previous studies argue that banks with hedging positions could also suffer increased default 
risk due to credit contagion or the failure of counterparties to honour their promises to protect the banks against default risk (Sjostrom, 2009; Stulz, 2010). This calls into question the effectiveness of CDS in credit risk management.

The remainder of this paper is organised as follows. Section 2 presents the literature review and development of hypotheses. Section 3 describes the sample construction, data and variables used in this study. Section 4 describes the empirical analysis and discussion of results. Section 5 provides a conclusion.

\section{LITERATURE REVIEW AND DEVELOPMENT OF HYPOTHESES}

\subsection{Risk management theory: credit default swaps and managerial risk aversion}

Hedging with derivatives can be used to diversify firm-specific risk (Tufano, 1996; Jin and Jorion, 2006; Gao, 2010). The risk diversification potential offered by credit derivatives has been widely discussed and acknowledged (Hirtle, 2009). CDS, which represent the largest segment of the credit derivatives market, are considered to be important instruments that enable banks to manage their portfolio of credit risks more efficiently (Minton et al., 2009). These instruments create new hedging opportunities with a new, less expensive way to hedge or transfer credit risk to other entities (Ashcraft and Santos, 2009). Prior to the financial crisis, banks had dramatically increased their risk transfer activities through the use of CDS (Nijskens and Wagner, 2011).

Bank managers are undoubtedly responsible for decision-making on behalf of shareholders, although a difference in risk preferences between managers and shareholders is not uncommon (Stulz, 1984; Rajgopal and Shevlin, 2002). It is not impossible for a bank manager to be driven more by the need to protect their own interest in a risk management decision concerning the bank (Smith and Stulz, 1985). In particular, a manager's risk aversion can motivate a decision to use CDS to reduce the bank's credit risk more than may be desirable from the perspective 
of shareholders. This situation is described as the risk-related incentive problem (Rajgopal and Shevlin, 2002).

The risk-related incentive problem will arise when the manager is less diversified than shareholders, and has limited ability to diversify his wealth, which is tied to the value of the bank he manages (Jensen and Meckling, 1976). In this situation, the values of the manager's human capital and compensation or wealth are linked to the ongoing existence of the firm. This implies that an investment in a risky project would benefit (well-diversified) shareholders if the project is successful. But, if the project fails, it would be detrimental to the (less-diversified) manager, who risks losing his job and future flow of income (Jensen and Meckling, 1976; Tufano, 1996). These risky prospects would encourage the manager to implement a risk management strategy such as using CDS to hedge the bank's credit risk. However, this risk management strategy is not necessarily in the best interest of the bank's shareholders, who would prefer managers to undertake risky strategies for the sake of greater returns.

\subsection{Agency theory: stock options as disincentives for risk management}

In comparison to managers, shareholders can diversify away their exposure to the nonsystematic risk of a particular bank by holding a sufficiently large basket of assets in their investment portfolios. This assumption of modern portfolio theory considers shareholders as risk-neutral investors. If this assumption holds, shareholders would prefer greater managerial risk-taking; hence, using CDS to reduce exposure to credit risk would be inconsistent with their interests. However, undiversified managers would prefer risk reduction to protect their interests; hence, CDS will be used to hedge against the exposure to credit risk (Stulz, 1984; Smith and Stulz, 1985; Graham and Rogers, 2002; Nijskens and Wagner, 2011; Fung et al., 2012). 
That said, although it can be argued that risk management is likely to be implemented by risk-averse managers mainly to reduce the bank's risk in the pursuit of managers' own interests, the managers are not necessarily risk-averse. This is because their risk-taking appetites can be enhanced by paying the managers stock options. Studies have indeed suggested that the riskrelated incentive problem between managers and shareholders as described above can be mitigated by including stock options in the managerial pay package (Stulz, 1984; Smith and Stulz, 1985; Tufano, 1996; Buck et al., 2003).

Stock options have a convex payoff structure. The convexity of stock options is measured by vega (Core and Guay, 2002). Vega is the sensitivity of the option value with respect to a $1 \%$ change in stock volatility. This means that stock option holders face negligible downside risk when the underlying stock price falls below the predetermined exercise price, but can earn enormous payoff when the price exceeds the exercise price. It follows that greater volatility will provide greater upside potential for the stock price and, consequently, for option values.

If hedging against credit risk is perceived to reduce a bank's stock volatility (Nijskens and Wagner, 2011), then managers who hold stock options will have little incentive to use CDS for hedging purposes, because such a strategy will reduce stock volatility and their option values (Smith and Stulz, 1985; Core and Guay, 2002). Therefore, we conjecture that greater stock options' vega will disincentivize hedging against credit risk, and hence result in little use of CDS for credit risk management purposes.

\subsection{Development of hypotheses}

\subsubsection{Stock options and credit default swaps for risk management in banks}

In the banking industry, the use of stock options is prevalent, and the percentage of stock options relative to total managerial compensation has also increased compared to industrial firms (Chen et al., 2006). Vega, as the risk-related incentive component of stock options, has 
been considered an important determinant of corporate risk management involving derivatives use (Tufano, 1996; Gay and Nam, 1998; Guay, 1999; Rajgopal and Shevlin, 2002; Rogers, 2002; Adkins et al., 2007; Supanvanij and Strauss, 2010). While CDS are predominantly used by banks, it is largely unknown whether the purpose of usage can be influenced by stock options' vega. This is because previous studies focus only on other types of derivatives used by non-financial firms.

Appendix A summarises empirical studies that have examined the use of stock options and non-credit derivatives by mainly non-financial firms. These studies were driven by the assumption that managerial risk aversion motivates corporate hedging with derivatives. Although a negative relationship between the use of derivatives and stock options is commonly documented, contradictory findings can also be observed (Géczy et al., 1997; Gay and Nam, 1998). The mixed findings call for further research in this area, especially in the context of the banking industry, which is currently understudied.

To our knowledge, empirical evidence on the relationship between the risk-related incentive component of stock options and the use of CDS for hedging in the banking industry is non-existent. A focus on banks is imperative, given the fact that banks are recognised as a major participant in the credit derivatives market that is dominated by CDS (BBA, 2006). Examining CDS is interesting because banks do not necessarily use these derivatives to manage or transfer credit risk away from their balance sheets. Studies have suggested that banks also take on new credit risk through their trading of these derivatives (Instefjord, 2005; Minton et al., 2009; Nijskens and Wagner, 2011).

Our study focuses on the use of CDS for hedging purposes in banks. This is founded on risk management theory. In this context, banks are in the position to buy CDS with a view to reduce exposure to the credit risk of their risky assets. It is plausible for this hedging activity 
to be restrained by the risk-taking appetites of the banks' CEOs, who are deemed influential in making decisions on behalf of shareholders. A CEO whose risk-taking appetite is enhanced through the implementation of greater stock option vega will have little incentive to reduce a bank's exposure to credit risk if doing so will reduce stock volatility and hence option values. Based on an assumed link between credit risk and stock volatility, we conjecture that the implementation of greater vega for bank CEOs will disincentivize the use of CDS for hedging purposes. This leads us to the first hypothesis:

H1: CEO vega is negatively related to the proportion of CDS held for hedging purposes.

Although the focus of the present study is on the use of CDS for hedging purposes, a robustness check is also performed by considering CDS held for trading purposes. This is to ensure that the analysis is not impaired by a possible misclassification error between hedging and trading purposes. The involvement of banks in the trading of CDS as part of risk-taking activity is widely acknowledged (Minton et al., 2009; Stulz, 2010; Corsi et al., 2011; Nijskens and Wagner, 2011). In this context, one can argue that the risk-taking incentives generated by stock options can incentivize selling of CDS that would load a bank's investment portfolios with new credit risk. Being on the selling side of the contracts will cause banks' stock volatility, and hence stock options' value, to increase, which is consistent with the CEOs' interest in stock options. Therefore, we conjecture that the implementation of greater vega for bank CEOs will incentivize the use of CDS for trading purposes as described above. This leads us to the second hypothesis:

H2: CEO vega is positively related to the proportion of CDS held for trading purposes.

\subsubsection{Credit default swaps and default risk in crisis periods}

The risk management literature suggests that derivatives used for hedging purposes will reduce risk, and hence reducing stock return volatility (Smith and Stulz, 1985; Hentschel and Kothari, 2001; Stulz, 2004; Fung et al., 2012). Minton et al. (2009) examine banks' use of 
credit derivatives in the United States. They use a sample of 395 banks from 1999 to 2005 and find that only 23 large banks, out of 395, used credit derivatives, and most of their derivatives positions were held for trading activities rather than for hedging of loans (i.e. risky assets). They note that the use of credit derivatives by banks to hedge loans is limited, while the effect is largely unknown.

Nijskens and Wagner (2011) examine the relationship between bank credit risk transfer activities and bank risk. They focus on the association between the use of CDS and banks' risk as measured by beta. The sample consists of 38 banks from 1998 to 2006 . They find that the use of CDS is associated with an increase in a bank's risk. They believe that the use of CDS increases bank risk because banks trade them to source new credit risk.

Fung et al. (2012) examine the effects of CDS usage on the risk profile and firm value of US insurance companies for the period 2001-2009. They use a sample of 113 Property/Casualty (PC) and 78 life insurance companies. They distinguish between the usage of CDS for hedging purposes and for income generation or trading purposes. They find that the use of CDS for hedging purposes is not necessarily negatively related to firm risk.

Other studies have examined derivatives other than CDS. Their findings are listed in Appendix B. First, it can be observed that previous findings are generally mixed. Second, the effect of derivatives use on default risk has not been investigated. These factors justify the need to investigate the link between default risk and the use of CDS, especially in the context of the banking industry, which has predominantly used these derivatives. The absence of definitive findings in previous studies as reflected from the mixed results, provides little guidance in terms of the expected direction for the relationship between CDS and default risk.

Although our first hypothesis implies that managers with lower vega will be more likely to use CDS for hedging purposes, the effect of such hedging activity is understandably beyond 
managers' control. Based on previous studies (Stulz, 2010; Nijskens and Wagner, 2011; Fung et al., 2012), we argue that the use of CDS even for hedging purposes is likely to attract an unintended effect in times of systemic credit crisis. This is a plausible scenario because the default protections promised through these derivatives will be no longer available when insurers (sellers) themselves fail on their obligations to protect buyers against the defaults of underlying securities (Sjostrom, 2009; Stulz, 2010). In this case, hedgers are no longer protected from the default risk of their risky assets, and expose to a portfolio of credit risk that is greater than they had accounted for. In this situation, the negative news could trigger increased default risk for both buyers and sellers of CDS through the counterparty risk channel of credit contagion (Jorion and Zhang, 2009). This argument leads to the third hypothesis:

H3: The proportion of CDS held by banks is positively related to default risk in the crisis period.

To test this hypothesis, the analysis is broken down into three distinct periods: prior to the financial crisis, the period of the financial crisis and the post-crisis period. As part of our robustness check, we distinguish between the usage of CDS for hedging purposes and for trading purposes.

\section{DATA AND VARIABLES}

\subsection{Sample}

This study is based on a sample of European publicly listed banks. The final sample consists of 60 banks and covers the period from 2006 to 2011. The list of European banks was drawn from two categories: European stock market indices and premier indices of the European Union countries (EU-27) (Fasshauer et al., 2008). The constituents of these two categories were 112 banks, in which 38 banks were cross-listed. This means there were effectively only 74 banks after considering the cross-listing factor. The final sample of 60 banks was derived after 
excluding 14 banks based on the reasons set forth in Table 1. In brief, the final sample comprises banks that were listed on 22 European stock market indices and included in one of three European indices (i.e., FTSE Eurotop 100 Index, FTS Eurofirst 300 Index and Euronext100). The sample construction is summarised in Table 1.

Insert Table 1 about here

\subsection{Variables}

\subsubsection{Credit default swaps held by banks}

The adoption of International Accounting Standard (IAS) No. 39 on Financial Instruments: Recognition and Measurement, which became effective from the reporting period beginning on 1 January 2005, has enriched the disclosure of derivatives use by European banks. The disclosures of derivatives use under this international regime are more systematic and standardised across banks. Prior to 2005, most European banks applied domestic accounting standards, which differ significantly between countries. The year 2005 is excluded from our sample because it represents a transition period from the domestic accounting system to the international accounting regime.

The international accounting regime requires users of derivatives to disclose in their annual reports the objectives for holding derivatives (Barth and Landsman, 2010). Users of derivatives are also expected to distinguish between derivatives held for hedging purposes and those held for trading purposes. The notional amounts of CDS held for hedging as reported in the banks' annual reports are used to gauge the extent of such hedging activity. As part of our robustness checks, we also collect data on the notional amounts of CDS used for trading purposes. 
Notional amounts were commonly considered in previous studies on derivatives (e.g., Gay and Nam, 1998; Hentschel and Kothari, 2001; Supanvanij and Strauss, 2010). We do not use the fair values of derivatives, because such information was not disclosed adequately across banks, as the option for fair value recognition was carved out from the adoption of IAS 39, implemented at the start of 2005 (European Commission, 2004).

\subsubsection{Stock options'vega}

We employ a methodology developed by Core and Guay (2002) in measuring the risktaking incentives arising from CEO stock options. Core and Guay's approximation method is widely used in the stock option compensation literature (e.g., Rajgopal and Shevlin, 2002; Coles et al., 2006; Hagendorff and Vallascas, 2011). In this context, vega is commonly measured based upon the partial derivative of the dividend-adjusted Black-Scholes equation with respect to the annual standard deviation of stock returns. The partial derivative is then multiplied by 0.01 to represent the pound change in an option value resulting from a $1 \%$ change in the standard deviation. The risk-taking incentive is then estimated by multiplying the generated value by the number of stock options held (Guay, 1999; Core and Guay, 2002; Rogers, 2002; Hagendorff and Vallascas, 2011; Gao, 2010). ${ }^{1}$ Further details are presented in Appendix C. The values of a stock option's parameters, such as the exercise price and time to expiry, were hand-collected from the banks' annual reports. Other data were collected from Datastream.

\subsubsection{Default risk}

A bank's default risk is measured through the Merton Distance-to-Default (DD) model, which is commonly used in previous studies (Gropp et al., 2006; Akhigbe et al., 2007; Bharath

\footnotetext{
${ }^{1}$ Vega for stock holdings is zero (Guay, 1999). Following prior literature, the calculation of vega is based on stock options compensation (e.g. Rogers, 2002; Fahlenbrach and Stulz, 2011; Hagendorff and Vallascas, 2011).
} 
and Shumway, 2008; Campbell et al., 2008; Vallascas and Hagendorff, 2011). This model provides a direct assessment of default likelihood using both accounting and market data (Saldías, 2013). An advantage of using the DD model to capture a bank's default risk is that it implicitly captures the bank's expected returns via the inclusion of the market value of assets (Hagendorff and Vallascas, 2011).

The model shown in Appendix $\mathrm{C}$ considers the book values of liabilities and market valuation of assets in estimating default risk. The 'distance to default' represents the number of standard deviations away from the default point, where the default point is defined as the point when the value of a bank's assets is equal to the value of its liabilities (Gropp et al., 2006). It is considered an appropriate indicator of default risk because it accounts for three crucial factors of fragility: the market value of assets, leverage and the volatility of assets (Gropp et al., 2006; Hagendorff and Vallascas, 2011).

In this study, distance to default is calculated for each bank in the sample and for each time period, using the prevailing period's equity market data and balance sheet data. Data to compute annual distance to default were gathered from Datastream and input into the formula shown in Appendix C. A shorter distance to default (i.e., lower distance to default) indicates higher default risk (Gropp et al., 2006).

\subsubsection{Other variables}

Appendix D lists the control variables and their definitions used in this study. Data on compensation (salary, bonuses, stock grants), CEO characteristics (ownership, age and tenure) and banks' diversification were hand-collected. Data for other bank characteristics were downloaded from Datastream. The country-specific factor is controlled through the levels of local competition based on the number of banks in each country. According to Cournovian's partial equilibrium model, there is a positive relationship between the degree of competition 
and the number of firms (Fama and Laffer, 1972). We also use country dummy as a robustness check. In addition, we incorporate non-performing loans (NPLs) as another country-specific variable. The NPLs are based on the average ratios of NPL across banks in each country (value equals one if the NPL ratio is lower than the average NPL ratio of European banks, and zero otherwise). The ratios are based on the report produced by the European Banking Authority (EBA, 2015).

\section{EMPIRICAL ANALYSIS AND RESULTS}

\subsection{Descriptive statistics and correlations}

Panel 1 of Table 2 reports the descriptive statistics of variables used in the regression analysis. As reported, the average notional amount of CDS held for hedging is $£ 1.59$ billion, while the average notional amount held for trading is $£ 151.43$ billion. Consistent with the findings in Nijskens and Wagner (2011) and Minton et al. (2009), CDS used for trading purposes represents a significant portion of the average notional amount of CDS held by our sample banks. That said, the focus of our study is on risk management, and hence the amount of CDS held for hedging.

Insert Table 2 about here

It is important to highlight here that our study reports the notional amounts of CDS held by a sample of European banks, which have not been documented elsewhere. For benchmarking purposes, the total notional amount of credit derivatives held by large banks in the United States was $\$ 5,526$ billion in 2005 (Minton et al., 2009). The average total notional amount of CDS used by 30 life insurance firms in the United States during the 2001-2009 period was $\$ 590$ billion (Fung et al., 2012). 
Table 2 also reports that the average natural logarithm of stock options' vega is 2.40 . The monetary value of vega is $£ 23,264$, which is significantly lower than the $\$ 155,523$ reported for a sample of banks in the United States (Belkhir and Boubaker, 2013). It is plausible for risktaking incentives in the United States to be generally higher than in Europe. This observation is consistent with Conyon and Murphy's (2000) suggestion that American executives may be less risk-averse than their counterparts elsewhere. The perceived conservativeness of CEOs in European banks simply reinforces the relevance of credit-risk hedging activities and the need for risk-taking incentives, which are the focus of the present study. Panel 2 of Table 2 shows the mean distribution of data by country, with a focus on countries with significant observation of hedging with CDS.

Table 3 reports the correlations among explanatory variables. Given the high correlation coefficients among few variables, regression diagnostic tests were performed to determine the variance inflation factors (VIF) for the variables. This post-estimation test is used to detect the presence of a serious multicollinearity problem in each regression specification. We reduce the possibility of a serious multicollinearity problem by ensuring that the variance inflation factors (VIF) for independent variables are less than 10 (Gujarati, 2003).

\section{Insert Table 3 about here}

\subsection{Regression models}

Tobit and panel data regressions are employed to test the first hypothesis. ${ }^{2}$ This is to examine the relationship between CEOs' risk-taking incentives (vega) and the proportion of CDS held by banks for hedging purposes. Model (1) below shows that vega is a key explanatory

\footnotetext{
${ }^{2}$ Both fixed- and random-effects estimations were employed. The results of random effects are reported and preferred based on the results of the Hausman test.
} 
variable that is deemed capable of influencing the extent of hedging position in CDS, as denoted by CDS-hedging in Equation (1) below:

$$
\text { CDS-hedging }=f(\text { Vega }+ \text { control variables })
$$

To test the second hypothesis, which is part of the robustness check, the proportion of CDS held by banks for trading purposes is used as the dependent variable. Stock options' vega remains the key explanatory variable, as illustrated in Equation (2) below:

$$
\text { CDS-trading }=f(\text { Vega }+ \text { control variables })
$$

Logit regressions were also employed to test the first and second hypotheses as part of the robustness check. For the third hypothesis, the effect of CDS use on a bank's default risk, as measured by the Merton distance to default, is tested using two-stage least squares regression (2SLS). Predicted values of the notional amount of CDS held scaled by total assets were used as the key explanatory variable in Equation (3) below. This implies that the variable is modelled as an endogenous variable:

$$
\text { Default risk }=f[\text { CDS (predicted })+\text { control variables }]
$$

CDS (predicted) is endogenously determined by stock options' vega, salary, derivativeshedging, derivatives-trading, leverage and others. Salary is considered an instrumental variable. To produce meaningful results, the regression analysis is performed for three different periods. The first is the period before the financial crisis (2006), the second is the period of the financial crisis (2007-2009), and the third is the period after the financial crisis (2010-2011). For robustness, the regression analysis in Equation (3) above is performed separately for CDS held for hedging and those held for trading purposes.

\subsection{Regression results}

\subsubsection{Stock options and credit default swaps for risk management in banks}


The regression results in relation to the first hypothesis are presented in Table 4. The dependent variable for Columns 1-3 is the extent of hedging positions in CDS. This is measured by the ratio of the notional amount of CDS held for hedging to the total notional amount of CDS held (i.e. trading plus hedging purposes) at date $t+1$. Columns $1,4,5$ and 6 of Table 4 report the results for the full sample (i.e., 300 observations), while Columns 2 and 3 report the results for the subsample containing only users of CDS (i.e., 134 observations).

Insert Table 4 about here

As a robustness check, for Column 4, the dependent variable is equal to one if the firm uses CDS for hedging purposes, and zero otherwise. For Column 5, the dependent variable is the notional amount of CDS held for hedging at date $t+1$. For Column 6 , the dependent variable is the notional amount of CDS held for hedging scaled by total assets at date $t+1$.

Overall, Table 4 reports that CEOs' risk-taking incentives, as measured by vega, are negatively related to the use of CDS for hedging purposes. The significance and negative beta coefficients on vega support our first hypothesis. The findings are consistent with the notion that risk-taking incentives provided by stock options disincentivize banks' CEOs from using CDS as risk management tools to hedge credit risk. CEOs with stock options are less likely to use CDS to hedge credit risk. This is because they perceive that doing so will reduce the volatility of the banks' stock returns, and hence the value of their stock options.

Our findings on CEOs' reluctance to hedge in the presence of stock options are consistent with the findings in previous studies that have suggested the role of stock options in reducing hedging intensity. For example, based on a sample of oil and gas producers, Rajgopal and Shevlin (2002) document that the incentives generated by stock options exhibit a negative relation with oil price hedging. Our findings enrich the literature by expanding the scope of 
investigation to credit risk hedging in the banking industry. This is novel empirical evidence that suggests stock options are disincentives to buying CDS for hedging purposes.

As part of our robustness checks, we then test the second hypothesis by using trading positions in CDS as the dependent variable. The variable is measured by the ratio of the notional amount of CDS held for trading to the total notional amount of CDS held (i.e. trading plus hedging purposes) at date $t+1$. The results are reported in Table 5 .

Insert Table 5 about here

Overall, Table 5 reports that CEOs' risk-taking incentives are positively related to trading position in CDS. The significant and positive beta coefficients on vega support our second hypothesis. The findings are consistent with the notion that risk-taking incentives provided by stock options incentivize banks' CEOs to use CDS to source new credit risk, as in the case of selling instead of buying the derivatives. This strategy will increase the volatility of the banks' stock returns, and in turn the value of stock options, in the interest of the CEOs. Although this risky strategy is in alignment with the interests of shareholders, taking on new credit risk through selling CDS can increase the bank's default risk. The risk can be catastrophic in periods of systemic credit crisis (Rajan, 2006). This leads to our next investigation on default risk in relation to the use of CDS.

\subsubsection{Credit default swaps and default risk}

An investigation of the relationship between the use of CDS and the default risk in the banking industry is related to our third hypothesis. The findings of previous studies in this area are mixed, which warrants the need for further investigation. Given that default risk increased systemically during the crisis that erupted in 2007 , we split the sample into three subsamples. 
The first represents a period before the financial crisis (2006), the second is the period of the financial crisis (2007-2009) and the third is the period after the financial crisis (2010-2011).

The dependent variable is a bank's distance to default, as measured through the formula shown in Appendix C. Shorter (or lower value of) distance to default indicates higher default risk. The first analysis uses CDS-hedging (predicted) as a key explanatory variable. CDShedging is measured as the total notional amount of CDS held for hedging scaled by total assets. CDS-hedging (predicted) is endogenously determined by stock options' vega and other variables, which can be implied through the (first-stage) regression results presented in Column 6 of Table 4. Other variables include salary, derivatives-hedging, derivatives-trading and leverage. The second-stage regression results are presented in Table 6 . Column 6 of Table 4 shows that salary is negatively related to CDS-hedging, while Table 6 shows salary is not significantly related to default risk. Therefore, salary is considered an instrumental variable in this context.

Insert Table 6 about here

Columns 1 and 2 of Table 6 report statistically significant coefficients between the variable CDS-hedging (predicted) and banks' distance to default, which is consistent with our third hypothesis. Interestingly, the sign of coefficients is negative. These suggest that hedging with CDS coincides with greater default risk in the period before and during the crisis. This finding is consistent with that documented in Fung et al. (2012), which suggests that the hedging effect of CDS may not necessarily materialise in the anticipated direction.

It is important to note that the variable CDS-hedging we employ here represents only a negligible part of banks' CDS portfolios. Previous studies have suggested that CDS were mainly used for income generation, rather than hedging (Minton et al., 2009; Nijskens and 
Wagner, 2011). Therefore, the hedging effect may be insignificant to reduce banks' default risk, especially in times of systemic credit crisis, when the ability of insurers to fulfil their obligations to protect as promised through the swap contracts is suspect.

That said, we now turn to the second analysis that identifies CDS-trading as a key explanatory variable for default risk. CDS-trading is measured as the total notional amount of CDS held for trading scaled by total assets. CDS-trading (predicted) is endogenously determined by stock options' vega and other variables, as shown in Column 6 of Table 5. The second-stage regression results are presented in Table 7.

Insert Table 7 about here

The results reported in Columns 1 and 2 of Table 6 demonstrate significant coefficients between the variable CDS-trading (predicted) and banks' distance to default, which is again consistent with our third hypothesis. The negative coefficients imply that trading positions in CDS are associated with greater default risk. This finding is very much anticipated, as trading positions in CDS are likely to involve taking on additional credit risk in investment portfolios. This risky strategy will definitely increase the bank's default risk, especially in the period leading up to the systemic credit crisis, when the bank may encounter a liquidity crisis and consequently fail to honour its 'promise to protect' under the swap contracts.

Quite unexpectedly, banks' involvement in CDS for hedging may be viewed rather negatively by the market. This notion is supported by Nijskens and Wagner's (2011) findings that suggest a bank's beta increased at the onset of its involvement in CDS. In this case, default risk can be expected to increase as well. This effect should be more apparent as early as the year immediately before the crisis, when the market would have anticipated the failures of CDS' sellers to honour their obligations, as in the case of the American International Group, 
Inc. (AIG) (Sjostrom, 2009). When insurers failed to fulfil their obligations, the default protection promised by CDS turned out to be illusionary (Stulz, 2010). In this case, hedgers are no longer protected, and become exposed to credit risk that is greater than they had previously managed and accounted for.

\section{CONCLUSION}

To our knowledge, empirical evidence on the relationship between the use of stock options and CDS for hedging purposes in the banking industry is non-existent. Focusing on banks is imperative given the fact that banks are recognised as a major participant in the credit derivatives market that is dominated by CDS. Knowing that risk appetites at banks can be incentivized through the use of stock options, this poses the question of whether such a commonly implemented pay practice disincentivizes the use of CDS for risk management in banks.

In this study, data of CEO stock options and the notional amount of CDS held for hedging by European banks during the period 2006-2011 were examined. We find that CEO vega is negatively related to the proportion of CDS held by banks for hedging. Robustness checks show that such a negative relationship does not hold when CDS are held for trading purposes. The results, taken together, suggest the role of stock options' vega as a disincentive for hedging positions, and an incentive for trading positions in CDS contracts.

In further analysis, we find that the extent of CDS held by banks is related to default risk during the period leading up to the financial crisis that erupted in 2007. In times of systemic credit crisis, a bank's default risk increases even with hedging positions in CDS. During such a period, default protection promised by swap contracts may no longer be available when insurers (sellers) themselves fail in their obligation to protect. In this case, hedging positions are no longer protected from the default risk of their risky assets, and become exposed to a 
portfolio of credit risk that is greater than they had anticipated. This means that the systemic condition can only increase the default risk for both buyers and sellers of CDS.

In conclusion, although it can be gathered from our findings that restraining the use of stock options can incentivize credit risk hedging, this measure will not necessarily lower default risk. The effectiveness of CDS as credit risk management instruments is questionable. This is because the intended hedging effect of CDS is likely to be constrained by factors that are within the control of neither the hedgers nor their managers. Negative market perception coupled with illusive protection associated with CDS is perhaps a manifestation of (undiversified) counterparty risk. Managing this risk will require a solution that goes beyond restraining the use of stock options. 


\section{REFERENCES}

Adam, T., Guettler, A., 2010. The use of credit default swaps by U.S. fixed-Income mutual funds. FDIC Working Paper 2011-01, Available at: http://papers.ssrn.com/sol3/papers.cfm?abstract_id=1982113 (Accessed date: 31 August 2016).

Adkins, L., Carter, D., Simpson, W., 2007. Managerial incentives and the use of foreign exchange derivatives by banks. The Journal of Financial Research 30, 399-413.

Akhigbe, A., Madura, J., Martin, A.D., 2007. Effect of Fed policy actions on the default likelihood of commercial banks. Journal of Financial Services Research 30, 147-162.

Allayannis, G., Ofek, E., 2001. Exchange rate exposure, hedging, and the use of foreign currency derivatives. Journal of International Money and Finance 20, 273-296.

Aretz, K., Bartram, S., 2010. Corporate hedging and shareholder value. The Journal of Financial Research 33, 317-371.

Ashcraft, A., Santos, J., 2009. Has the CDS market lowered the cost of corporate debt? Journal of Monetary Economics 56, 514-523.

Bakke, T., Mahmudi, H., Fernando, C., Salas, J., 2016. The causal effect of option pay on corporate risk management. Journal of Financial Economics 120, 623-643.

Barth, M.E., Landsman, W.R., 2010. How did financial reporting contribute to the financial crisis? European Accounting Review 19, 399-423.

Bartram, S.M., Brown G.W., Conrad, J., 2011. The effects of derivatives on firm risk and value. Journal of Financial and Quantitative Analysis 46, 967-999. 
Bartram, S.M., Brown, G.W., Fehle, F.R., 2009. International evidence on financial derivatives usage. Financial Management 38, 185-206.

Bebchuk, L.A., Cohen, A., Spamann, H., 2010. The wages of failure: executive compensation at Bear Stearns and Lehman 2000-2008. Yale Journal on Regulation 27, 257-282.

Belkhir, M. Boubaker, S., 2013. CEO inside debt and hedging decisions: Lessons from the U.S. banking industry. Journal of International Financial Markets, Institutions and Money 24, 223246.

Bharath, S., Shumway, T., 2008. Forecasting default with the Merton Distance to Default Model. Review of Financial Studies 21, 1339-1369.

British Bankers Association, 2006. BBA credit derivatives report 2006. London: British Bankers Association.

Buck, T., Bruce, A., Main, B.G.M., Udueni, H., 2003. Long term incentive plans, executive pay and UK company performance. Journal of Management Studies 40, 1709-1727.

Campbell, J., Hilscher, J., Szilagyi, J., 2008. In search of distress risk. Journal of Finance 63, 2899-2939.

Chen, C.R., Steiner, T.L., Whyte, A.M., 2006. Does stock option-based executive compensation induce risk-taking? An analysis of the banking industry. Journal of Banking and Finance 30, 915-945.

Chernenko, S., Faulkender, M., 2011. The two sides of derivatives usage: hedging and speculating with interest rate swaps. Journal of Financial and Quantitative Analysis 46, 7271754

Coles, J.L., Daniel, N.D., Naveen, L., 2006. Managerial incentives and risk-taking. Journal of Financial Economics 79, 431-468. 
Conyon, M.J., Murphy, K.J., 2000. The prince and the pauper? CEO pay in the United States and United Kingdom. The Economic Journal 110, F640-71.

Core, J.E, Guay, W., 2002. Estimating the value of employee stock option portfolios and their sensitivities to price and volatility. Journal of Accounting Research 40, 613-630.

Corsi, F., Hosni, H., Marmi, S., 2011. Risk allocation: The double face of financial derivatives. SSRN Working Paper. Available at: http://ssrn.com/abstract=1844288.

Duffee, G.R., Zhou, C., 2001. Credit derivatives in banking: Useful tools for managing risk? Journal of Monetary Economics 48, 25-54.

Duh, R.R., Hsu, A.W., Alves, P.A.P., 2012. The impact of IAS 39 on the risk-relevance of earnings volatility: Evidence from foreign banks cross-listed in the USA. Journal of Contemporary Accounting \& Economics 8, 23-38.

Ertugrul, M., Sezer, O., Sirmans, C., 2008. Financial leverage, CEO compensation, and corporate hedging: Evidence from real estate investment trusts. Journal of Real Estate Finance and Economics 36, 53-80.

European Banking Authority (EBA), 2015. Risk Assessment of the European Banking System. Luxembourg.

European Commission, 2004. IAS 39 Financial Instruments: recognition and measurement frequently asked questions. Press Release, MEMO/04/265.

Fahlenbrach, R., Stulz, R., 2011. Bank CEO incentives and the credit crisis. Journal of Financial Economics 99, 11-26.

Fama, E. U., Laffer, A. B., 1972. The number of firms and competition. American Economic Review 62, 670-674. 
Fasshauera, J.D., Glauma, M., Street, D.L., 2008. Adoption of IAS 19R by Europe's premier listed companies: Corridor approach versus full recognition Summary of an ACCA research monograph. Journal of International Accounting, Auditing and Taxation 17, 113-122.

Faulkender, M., 2005. Hedging or market timing? Selecting the interest rate exposure of corporate debt. Journal of Finance 60, 931-962.

Fortin, R., Goldberg, G.M, Roth, G. 2010. Bank risk taking at the onset of the current banking crisis. The Financial Review 45, 891-913.

Fung, H.G., Wen, M.M., Zhang, G., 2012. How does the use of credit default swaps affect firm risk and value? Evidence from US life and property/Casualty insurance companies. Financial Management 41, 979-1007.

Gao, H., 2010. Optimal compensation contracts when managers can hedge. Journal of Financial Economics 97, 218-238.

Gay, G.D., Nam, J., 1998. The underinvestment problem and corporate derivatives use. Financial Management 27, 53-69.

Géczy, C., Minton, B.A., Schrand, C., 1997. Why firms use currency derivatives. Journal of Finance 52, 1323-1354.

Géczy, C., Minton, B., Schrand, C., 2007. Taking a view: Corporate speculation, governance and compensation. Journal of Finance 62, 2405-2443.

Graham, J.R., Rogers, D.A., 2002. Do firms hedge in response to tax incentives? The Journal of Finance 57, 815-839.

Gropp, R., Vesala, J., Vulpes, G., 2006. Equity and bond market signals as leading indicators of bank fragility. Journal of Money, Credit and Banking 38, 399-428. 
Guay, W.R., 1999. The impact of derivatives on firm risk: An empirical examination of new derivative users. Journal of Accounting and Economics 26, 319-351.

Gujarati, D. N., 2003. Basic Econometrics. New York: McGraw Hill.

Hagendorff, J., Vallascas, F., 2011. CEO pay incentives and risk-taking: Evidence from bank acquisitions. Journal of Corporate Finance 17, 1078-1095.

Harada, K., Ito, T., Takahashi, S., 2010. Is the distance to default a good measure in predicting bank failures? Case studies. Working Paper 16182, National Bureau of Economic Research.

Hentschel, L., Kothari, S.B., 2001. Are corporations reducing or taking risks with derivatives? Journal of Financial and Quantitative Analysis 36, 93-118.

Hillegeist, S.A., Keating, E.K., Cram, D.P., 2004. Assessing the probability of bankruptcy. Review of Accounting Studies 9, 5-34.

Hirtle, B., 2009. Credit derivatives and bank credit supply. Journal of Financial Intermediation $18,125-150$.

Instefjord, N., 2005. Risk and hedging: Do credit derivatives increase bank risk? Journal of Banking \& Finance 29, 333-345.

International Swaps and Derivatives Association, 2010. ISDA Market Survey. Available at: www2.isda.org/attachment/Mjk5Nw==/ISDA-Market-Survey-results1987 June\%202010

Jensen, M., Meckling, W., 1976. Theory of the firm: managerial behaviour, agency costs, and ownership structure. Journal of Financial Economics 3, 305-360.

Jin, Y., Jorion, P., 2006. Firm value and hedging: evidence from U.S. oil and gas producers. The Journal of Finance 61, 893-919. 
Jorion, P., Zhang, G., 2009. Credit contagion from counterparty risk. Journal of Finance 64, 2053-2087.

Knopf, J., Nam, J., Thornton, J. 2002. The volatility and price sensitivities of managerial stock option portfolios and corporate hedging. Journal of Finance 57, 801-813.

Minhat, M., Abdullah, M., 2016. Bankers' stock options, risk-taking and the financial crisis, Journal of Financial Stability 22, 121-128.

Minton, B., Stulz, R., Williamson, R., 2009. How much do banks use credit derivatives to hedge loans? Journal of Financial Services Research 35, 1-31.

Nijskens, R., Wagner, W., 2011. Credit risk transfer activities and systemic risk: How banks became less risky individually but posed greater risks to the financial system at the same time. Journal of Banking and Finance 35, 1391-1398.

Rajan, R. G., 2006. Has finance made the world riskier? European Financial Management 12, 499-533.

Rajgopal, S., Shevlin, T., 2002. Empirical evidence on the relation between stock option compensation and risk taking. Journal of Accounting and Economics 33, 145-171.

Rogers, D., 2002. Does executive portfolio structure affect risk management? CEO risk-taking incentives and corporate derivatives usage. Journal of Banking and Finance 26, 271-295.

Saldías, M., 2013. Systemic risk analysis using forward-looking distance-to-default series. Journal of Financial Stability 9, 498-517.

Sarra, J., 2009. Financial market destabilization and the role of credit default swaps, University of Cincinnati Law Review, 78, 630-656.

Sjostrom, W.K., 2009. The AIG bailout. Washington and Lee Law Review 66, 943-991. 
Smith, C., Stulz, R., 1985. The determinants of firms' hedging policies. Journal of Financial and Quantitative Analysis 20, 391-405.

Stulz, R., 1984. Optimal hedging policies. Journal of Financial and Quantitative Analysis 19, 127-140.

Stulz, R., 2004. Should we fear derivatives? The Journal of Economic Perspectives 18, 173192.

Stulz, R.M., 2010. Credit default swaps and the credit crisis. Journal of Economic Perspectives 24, 73-92.

Supanvanij, J., Strauss, J., 2010. Corporate derivative use and the composition of CEO compensation. Global Finance Journal 21, 170-185.

Tufano, P., 1996. Who manages risk? An empirical examination of risk management practices in the gold mining industry. Journal of Finance 51, 1097-1137.

Vallascas, F, Hagendorff, J., 2011. The impact of European bank mergers on bidder default risk. Journal of Banking and Finance 35, 902-915. 
TABLE 1

Sample Construction

\begin{tabular}{|c|c|c|}
\hline Sample selection criteria & & $\begin{array}{l}\text { No. of } \\
\text { banks }\end{array}$ \\
\hline \multicolumn{3}{|l|}{ Category 1} \\
\hline \multirow{3}{*}{$\begin{array}{l}\text { Banks listed in the European stock } \\
\text { market indices }\end{array}$} & FTSE Eurotop 100 Index & 13 \\
\hline & FTSEurofirst 300 Index & 21 \\
\hline & Euronext100 & 6 \\
\hline \multicolumn{3}{|l|}{ Category 2} \\
\hline $\begin{array}{l}\text { Banks included in the premier } \\
\text { indices of } 27 \text { European countries }\end{array}$ & Premier segment of 27 European stock exchanges & 72 \\
\hline \multirow[t]{2}{*}{ Cross-listed } & Listed on more than one index & (38) \\
\hline & & 74 \\
\hline \multicolumn{3}{|l|}{ Elimination criteria } \\
\hline Annual report not available & English version of annual report not available & (1) \\
\hline Merger or acquisition & Merged or acquired during the sample period & (3) \\
\hline Missing data & $\begin{array}{l}\text { Banks that do not provide adequate details of CEO } \\
\text { compensation }\end{array}$ & (10) \\
\hline Total banks in the sample & & 60 \\
\hline
\end{tabular}


TABLE 2

\section{Panel 1 - Descriptive statistics}

\begin{tabular}{|c|c|c|c|c|}
\hline & Mean & Min & Max & Stdev \\
\hline CDS-trading (£mil) & 151,430 & 0 & $4,129,244$ & 476,902 \\
\hline CDS-hedging (£mil) & 1,592 & 0 & 114,422 & 10,117 \\
\hline CEO vega $(\ln )$ & 2.40 & -9.27 & 14.16 & 4.41 \\
\hline Salary $(£ 000)$ & 654 & 5 & 3,476 & 554 \\
\hline Bonus (£000) & 409 & 0 & 5,985 & 852 \\
\hline Stock grants $(£ 000)$ & 980 & 0 & 41,033 & 3,239 \\
\hline \%Ownership & 0.004 & 0 & 0.190 & 0.019 \\
\hline Derivatives-hedging (£mil) & 620,423 & 0 & $48,800,000$ & $4,837,875$ \\
\hline Derivatives-trading (£mil) & $2,302,121$ & 0 & $49,400,000$ & $7,292,426$ \\
\hline Investment opportunities & 1.35 & 0 & 6.35 & 0.98 \\
\hline Leverage & 0.32 & 0 & 0.93 & 0.19 \\
\hline Distance to default & 7.260 & 2.544 & 62.172 & 6.780 \\
\hline Size (£mil) & $2,328,592$ & 14 & $79,339,694$ & $10,021,541$ \\
\hline Diversification (no. of segments) & 3.64 & 1 & 10 & 2 \\
\hline Tenure & 5 & 1 & 28 & 4.057 \\
\hline Age & 54 & 35 & 70 & 7.271 \\
\hline
\end{tabular}


Panel 2 - Mean distribution by country

\begin{tabular}{|c|c|c|c|c|c|c|c|}
\hline & Germany & Italy & Spain & Denmark & France & Portugal & Others \\
\hline CDS-trading (£mil) & 1,328 & 24,753 & 16,825 & 0 & $1,019,752$ & 1,511 & 132,337 \\
\hline CDS-hedging (£mil) & 11,217 & 301 & 11,167 & 1,476 & 248 & 32 & 5 \\
\hline CEO vega $(\ln )$ & 0.00 & 2.66 & 0.78 & 4.95 & 6.12 & 0.43 & 2.44 \\
\hline Salary $(£ 000)$ & 781 & 741 & 1,338 & 596 & 719 & 518 & 546 \\
\hline Bonus $(£ 000)$ & 1,221 & 361 & 1,267 & 86 & 470 & 401 & 241 \\
\hline Stock grants $(£ 000)$ & 2,374 & 3 & 1,059 & 125 & 22 & 827 & 1,187 \\
\hline \%Ownership & 0.000 & 0.000 & 0.001 & 0.000 & 0.000 & 0.001 & 0.007 \\
\hline Derivatives-hedging ( $£$ mil) & $11,200,000$ & 41,974 & 43,139 & 14,471 & 365,308 & 9,415 & 41,701 \\
\hline Derivatives--trading (£mil) & $2,910,737$ & 487,333 & 605,041 & 23,086 & $14,500,000$ & 39,676 & $1,814,547$ \\
\hline Investment opportunities & 0.90 & 0.87 & 1.46 & 1.22 & 0.84 & 1.32 & 1.52 \\
\hline Leverage & 0.33 & 0.47 & 0.46 & 0.41 & 0.21 & 0.40 & 0.27 \\
\hline Distance to default & 18.678 & 7.604 & 6.994 & 7.073 & 8.811 & 11.178 & 5.690 \\
\hline Size (£mil) & $5,287,752$ & $1,243,075$ & $2,947,174$ & $1,487,958$ & $8,233,321$ & 438,669 & $1,777,613$ \\
\hline Diversification (no. of segments) & 4.44 & 2.39 & 3.47 & 6.00 & 6.08 & 5.54 & 3.19 \\
\hline Tenure & 3 & 4 & 5 & 12 & 4 & 6 & 5 \\
\hline Age & 56 & 53 & 58 & 59 & 56 & 61 & 52 \\
\hline
\end{tabular}


TABLE 3 - Correlations for explanatory variables

\begin{tabular}{|c|c|c|c|c|c|c|c|c|c|c|c|c|c|c|c|c|}
\hline & $\begin{array}{l}\text { CEO } \\
\text { vega }\end{array}$ & $\begin{array}{l}\text { Distance } \\
\text { to default }\end{array}$ & Volatility & Salary & Bonus & $\begin{array}{l}\text { Stock } \\
\text { grants }\end{array}$ & $\begin{array}{l}\text { Owner- } \\
\text { ship }\end{array}$ & $\begin{array}{l}\text { Derivatives } \\
\text { (hedging) }\end{array}$ & $\begin{array}{l}\text { Derivatives } \\
\text { (trading) }\end{array}$ & $\begin{array}{l}\text { Invest. } \\
\text { opp. }\end{array}$ & $\begin{array}{l}\text { Leve- } \\
\text { rage }\end{array}$ & Size & $\begin{array}{l}\text { Diversi- } \\
\text { fication }\end{array}$ & $\begin{array}{l}\text { Country } \\
\text { factor }\end{array}$ & NPLs & Tenure \\
\hline CEO vega & 1.000 & & & & & & & & & & & & & & & \\
\hline $\begin{array}{l}\text { Distance to } \\
\text { default }\end{array}$ & $-0.106^{*}$ & 1.000 & & & & & & & & & & & & & & \\
\hline Volatility & $0.190 * * *$ & $0.195 * * *$ & 1.000 & & & & & & & & & & & & & \\
\hline Salary & 0.086 & $0.133^{* *}$ & $0.231 * * *$ & 1.000 & & & & & & & & & & & & \\
\hline Bonus & $0.299 * * *$ & -0.032 & $0.158 * * *$ & $0.360 * * *$ & 1.000 & & & & & & & & & & & \\
\hline Stock grants & $0.104 *$ & -0.035 & 0.008 & $0.206^{* * *}$ & $0.234 * * *$ & 1.000 & & & & & & & & & & \\
\hline Ownership & -0.079 & $-0.101 *$ & $-0.115 * *$ & $-0.250 * * *$ & -0.010 & -0.061 & 1.000 & & & & & & & & & \\
\hline $\begin{array}{l}\text { Derivatives } \\
\text { (hedging) }\end{array}$ & 0.066 & -0.015 & $0.146^{* *}$ & $0.356^{* * * *}$ & $0.284 * * *$ & $0.133^{* *}$ & 0.148 & 1.000 & & & & & & & & \\
\hline $\begin{array}{l}\text { Derivatives } \\
\text { (trading) }\end{array}$ & $0.193 * * *$ & $-0.112 *$ & $0.161^{* * * *}$ & $0.441^{* * * *}$ & $0.258 * * *$ & $0.101 *$ & $-0.099^{*}$ & $0.063^{* * *}$ & 1.000 & & & & & & & \\
\hline Leverage & 0.010 & $0.165 * * *$ & 0.076 & $0.182^{* * * *}$ & $0.180 * * *$ & -0.068 & $-0.248 * * *$ & $0.102 *$ & 0.085 & -0.068 & 1.000 & & & & & \\
\hline Size & $0.262 * * *$ & 0.055 & $0.211 * * *$ & $0.154 * * *$ & $0.304 * * *$ & $0.131 * *$ & -0.052 & $0.106^{*}$ & 0.085 & 0.048 & 0.027 & 1.000 & & & & \\
\hline Diversification & $0.195 * * *$ & $0.155^{* * *}$ & $0.134 * *$ & $0.457^{* * *}$ & $0.200 * * *$ & $0.127 * *$ & $-0.155^{* * *}$ & $0.187^{* * *}$ & $0.210 * * *$ & $-0.214 * * *$ & 0.079 & $0.119^{*}$ & 1.000 & & & \\
\hline Country factor & $0.210 * * *$ & $0.154 * * *$ & 0.013 & $0.409 * * *$ & $0.290 * * *$ & $0.115^{*}$ & $-0.354 * * *$ & $0.145^{* *}$ & $0.291 * * *$ & $-0.134 * *$ & $0.109 *$ & $0.118^{*}$ & $0.158 * * *$ & 1.000 & & \\
\hline NPLs & $0.177 * * *$ & $0.191 * * *$ & $0.144 * *$ & $0.242 * * *$ & $0.114 * *$ & $0.245^{* * *}$ & 0.093 & $0.233 * * *$ & $0.271 * * *$ & $-0.154 * * *$ & -0.077 & $0.195^{* * * *}$ & $0.351 * * *$ & $0.172 * * *$ & 1.000 & \\
\hline Age & -0.083 & 0.021 & 0.005 & $0.261 * * *$ & $0.200^{* * * *}$ & 0.091 & 0.023 & $0.196^{* * * *}$ & $0.136^{* *}$ & $-0.096^{*}$ & -0.054 & 0.022 & $0.193 * * *$ & 0.077 & 0.028 & 1.000 \\
\hline Tenure & -0.009 & -0.069 & -0.022 & 0.004 & 0.014 & -0.067 & 0.044 & 0.080 & -0.013 & 0.026 & -0.026 & -0.048 & $0.127 * *$ & -0.014 & -0.060 & $0.339 * * * 1.000$ \\
\hline
\end{tabular}

Definitions of variables are available in Appendix D. ***,** and * show statistical significance at the $1 \%, 5 \%$ and $10 \%$ levels, respectively. 
TABLE 4

CEO risk-taking incentives (vega) and CDS for hedging purposes

\begin{tabular}{|c|c|c|c|c|c|c|}
\hline & $(1)$ & $(2)$ & (3) & $(4)$ & $(5)$ & (6) \\
\hline \multirow[b]{2}{*}{$\begin{array}{l}\text { Independent } \\
\text { variables }\end{array}$} & \multirow[b]{2}{*}{ Tobit } & \multirow[b]{2}{*}{ Tobit } & \multirow[b]{2}{*}{$\begin{array}{l}\text { Random } \\
\text { Effects }\end{array}$} & \multicolumn{3}{|c|}{ Robustness Check } \\
\hline & & & & Logit & Tobit & Tobit \\
\hline CEO vega & $\begin{array}{l}-0.029^{*} \\
(0.054)\end{array}$ & $\begin{array}{l}-0.056^{* * *} \\
(0.000)\end{array}$ & $\begin{array}{l}-0.007 * * \\
(0.056)\end{array}$ & $\begin{array}{l}-0.115^{* *} \\
(0.015)\end{array}$ & $\begin{array}{l}-0.781 * * \\
(0.036)\end{array}$ & $\begin{array}{l}-0.226^{* * * *} \\
(0.003)\end{array}$ \\
\hline Distance to default & $\begin{array}{r}-0.009 \\
(0.581)\end{array}$ & & $\begin{array}{r}0.000 \\
(0.939)\end{array}$ & $\begin{array}{c}-0.041 \\
(0.406)\end{array}$ & & \\
\hline Salary & $\begin{array}{r}-0.099 \\
(0.238)\end{array}$ & $\begin{array}{c}-0.156^{*} \\
(0.087)\end{array}$ & $\begin{array}{r}-0.051 \\
(0.131)\end{array}$ & $\begin{array}{r}-0.332 \\
(0.257)\end{array}$ & $\begin{array}{r}-1.728 \\
(0.442)\end{array}$ & $\begin{array}{l}-1.389 * * * \\
(0.000)\end{array}$ \\
\hline Bonus & $\begin{array}{r}0.026 \\
(0.260)\end{array}$ & $\begin{array}{c}0.040^{*} \\
(0.079)\end{array}$ & $\begin{array}{r}-0.001 \\
(0.887)\end{array}$ & $\begin{array}{l}0.146^{* *} \\
(0.042)\end{array}$ & $\begin{array}{c}1.128^{*} \\
(0.051)\end{array}$ & $\begin{array}{r}0.166 \\
(0.171)\end{array}$ \\
\hline Stock grants & $\begin{array}{r}0.000 \\
(0.500)\end{array}$ & $\begin{array}{r}0.000 \\
(0.419)\end{array}$ & $\begin{array}{l}0.024 * * * \\
(0.005)\end{array}$ & $\begin{array}{r}0.000 \\
(0.685)\end{array}$ & $\begin{array}{r}0.000 \\
(0.918)\end{array}$ & $\begin{array}{r}0.000 \\
(0.831)\end{array}$ \\
\hline Ownership & $\begin{array}{r}-1.114 \\
(0.943)\end{array}$ & $\begin{array}{r}-1.772 \\
(0.933)\end{array}$ & $\begin{array}{r}-2.519 \\
(0.320)\end{array}$ & $\begin{array}{r}5.909 \\
(0.754)\end{array}$ & $\begin{array}{l}55.415 \\
(0.901)\end{array}$ & $\begin{array}{r}-9.294 \\
(0.644)\end{array}$ \\
\hline Derivatives-hedging & $\begin{array}{l}0.151^{* * *} \\
(0.000)\end{array}$ & $\begin{array}{r}0.004 \\
(0.887)\end{array}$ & $\begin{array}{r}-0.015 \\
(0.134)\end{array}$ & $\begin{array}{l}0.484 * * * \\
(0.000)\end{array}$ & $\begin{array}{l}3.666^{* * *} \\
(0.000)\end{array}$ & $\begin{array}{l}0.844 * * * \\
(0.000)\end{array}$ \\
\hline Derivatives-trading & $\begin{array}{l}-0.043^{*} \\
(0.072)\end{array}$ & $\begin{array}{l}-0.075^{* * *} \\
(0.002)\end{array}$ & $\begin{array}{r}0.001 \\
(0.924)\end{array}$ & $\begin{array}{r}-0.019 \\
(0.873)\end{array}$ & $\begin{array}{r}-0.139 \\
(0.817)\end{array}$ & $\begin{array}{l}-0.256^{* *} \\
(0.042)\end{array}$ \\
\hline Invest. opportunities & $\begin{array}{r}-0.001 \\
(0.993)\end{array}$ & $\begin{array}{l}0.351 * * \\
(0.026)\end{array}$ & $\begin{array}{c}0.053^{*} \\
(0.067)\end{array}$ & $\begin{array}{r}-0.274 \\
(0.573)\end{array}$ & $\begin{array}{r}-1.368 \\
(0.711)\end{array}$ & $\begin{array}{r}-0.112 \\
(0.863)\end{array}$ \\
\hline Leverage & $\begin{array}{l}1.151^{* *} \\
(0.015)\end{array}$ & $\begin{array}{l}1.706^{* * * *} \\
(0.009)\end{array}$ & $\begin{array}{r}-0.206 \\
(0.483)\end{array}$ & $\begin{array}{l}6.155^{* * *} \\
(0.002)\end{array}$ & $\begin{array}{l}44.432 * * * \\
(0.001)\end{array}$ & $\begin{array}{c}2.886^{*} \\
(0.097)\end{array}$ \\
\hline Size & $\begin{array}{r}0.000 \\
(0.335)\end{array}$ & $\begin{array}{r}0.000 \\
(0.233)\end{array}$ & $\begin{array}{r}0.000 \\
(0.449)\end{array}$ & $\begin{array}{r}0.000 \\
(0.115)\end{array}$ & $\begin{array}{r}0.000 \\
(0.172)\end{array}$ & $\begin{array}{r}0.000 \\
(0.196)\end{array}$ \\
\hline Diversification & $\begin{array}{l}0.067 * * \\
(0.029)\end{array}$ & $\begin{array}{r}-0.007 \\
(0.816)\end{array}$ & $\begin{array}{r}0.003 \\
(0.831)\end{array}$ & $\begin{array}{l}0.293 * * * \\
(0.003)\end{array}$ & $\begin{array}{l}2.179 * * * \\
(0.005)\end{array}$ & $\begin{array}{r}0.093 \\
(0.543)\end{array}$ \\
\hline NPLs & $\begin{array}{l}-0.114 \\
(0.454)\end{array}$ & $\begin{array}{r}0.047 \\
(0.747)\end{array}$ & $\begin{array}{r}-0.124 \\
(0.345)\end{array}$ & $\begin{array}{r}-0.447 \\
(0.361)\end{array}$ & $\begin{array}{l}-4.557 \\
(0.212)\end{array}$ & $\begin{array}{l}-2.525 * * * \\
(0.001)\end{array}$ \\
\hline Country factor & $\begin{array}{l}0.475^{* * *} \\
(0.000)\end{array}$ & $\begin{array}{l}0.381 \text { *** } \\
(0.000)\end{array}$ & $\begin{array}{l}0.022 * * * \\
(0.008)\end{array}$ & $\begin{array}{l}1.561 \text { *** } \\
(0.000)\end{array}$ & $\begin{array}{l}12.880 * * * \\
(0.000)\end{array}$ & $\begin{array}{l}1.891 \text { *** } \\
(0.000)\end{array}$ \\
\hline Year dummy & Yes & Yes & & Yes & Yes & Yes \\
\hline No. Observations & 300 & 134 & 134 & 300 & 300 & 300 \\
\hline Pseudo $R^{2}$ & 0.310 & 0.320 & & 0.385 & 0.165 & 0.042 \\
\hline$R^{2}$ within & & & 0.159 & & & \\
\hline$R^{2}$ between & & & 0.327 & & & \\
\hline$R^{2}$ overall & & & 0.244 & & & \\
\hline
\end{tabular}

For Columns 1-3, the dependent variable is the extent of CDS held for hedging at date $t+1$, measured by the notional amount of the CDS used for hedging divided by total CDS usage (trading plus hedging). Columns 1, 4, 5 and 6 
report the results for the full sample, while Columns 2-3 report the results for the subsample containing only CDS users (i.e., only 134 bank-years used CDS). As a robustness check, for Column 4, the dependent variable is equal to 1 if the firm uses CDS for hedging purposes, and 0 otherwise. For Column 5, the dependent variable is the notional amount of CDS held for hedging at date $t+1$. For Column 6 , the dependent variable is the notional amount of CDS held for hedging scaled by total assets at date $\mathrm{t}+1$. All variables are defined in Appendix $\mathrm{D}$. The $\mathrm{p}$-values are reported in parentheses. $* * *, * *$ and $*$ show statistical significance at the $1 \%, 5 \%$ and $10 \%$ levels, respectively. 
TABLE 5

CEO risk-taking incentives (vega) and CDS for trading purposes

\begin{tabular}{|c|c|c|c|c|c|c|}
\hline & $(1)$ & $(2)$ & (3) & $(4)$ & $(5)$ & (6) \\
\hline \multirow[b]{2}{*}{$\begin{array}{l}\text { Independent } \\
\text { variables }\end{array}$} & \multirow[b]{2}{*}{ Tobit } & \multirow[b]{2}{*}{ Tobit } & \multirow[b]{2}{*}{$\begin{array}{l}\text { Random } \\
\text { Effects }\end{array}$} & \multicolumn{3}{|c|}{ Robustness Check } \\
\hline & & & & Logit & Tobit & Tobit \\
\hline CEO vega & $\begin{array}{l}0.030 * * * \\
(0.007)\end{array}$ & $\begin{array}{l}0.017 * * * \\
(0.006)\end{array}$ & $\begin{array}{c}0.007 * \\
(0.056)\end{array}$ & $\begin{array}{l}0.113^{* *} \\
(0.014)\end{array}$ & $\begin{array}{l}0.652 * * * \\
(0.001)\end{array}$ & $\begin{array}{l}0.320 * * * \\
(0.001)\end{array}$ \\
\hline Distance to default & $\begin{array}{r}-0.014 \\
(0.347)\end{array}$ & & $\begin{array}{r}-0.000 \\
(0.939)\end{array}$ & $\begin{array}{r}-0.020 \\
(0.565)\end{array}$ & & \\
\hline Salary & $\begin{array}{r}0.062 \\
(0.373)\end{array}$ & $\begin{array}{c}0.091 * \\
(0.066)\end{array}$ & $\begin{array}{r}0.051 \\
(0.131)\end{array}$ & $\begin{array}{r}0.171 \\
(0.474)\end{array}$ & $\begin{array}{r}1.443 \\
(0.274)\end{array}$ & $\begin{array}{l}-1.791^{*} \\
(0.093)\end{array}$ \\
\hline Bonus & $\begin{array}{c}0.032 * \\
(0.080)\end{array}$ & $\begin{array}{r}-0.014 \\
(0.226)\end{array}$ & $\begin{array}{r}0.001 \\
(0.887)\end{array}$ & $\begin{array}{c}0.107 * \\
(0.078)\end{array}$ & $\begin{array}{l}0.751^{* *} \\
(0.025)\end{array}$ & $\begin{array}{l}0.375^{* *} \\
(0.013)\end{array}$ \\
\hline Stock grants & $\begin{array}{r}0.000 \\
(0.555)\end{array}$ & $\begin{array}{r}0.000 \\
(0.233)\end{array}$ & $\begin{array}{l}-0.024 * * * \\
(0.005)\end{array}$ & $\begin{array}{r}0.000 \\
(0.838)\end{array}$ & $\begin{array}{r}0.000 \\
(0.405)\end{array}$ & $\begin{array}{r}0.000 \\
(0.704)\end{array}$ \\
\hline Ownership & $\begin{array}{r}-4.245 \\
(0.509)\end{array}$ & $\begin{array}{r}1.269 \\
(0.829)\end{array}$ & $\begin{array}{r}2.519 \\
(0.320)\end{array}$ & $\begin{array}{r}-17.248 \\
(0.676)\end{array}$ & $\begin{array}{r}-83.325 \\
(0.511)\end{array}$ & $\begin{array}{l}-51.176 * * \\
(0.041)\end{array}$ \\
\hline Derivatives-hedging & $\begin{array}{l}0.082 * * * \\
(0.001)\end{array}$ & $\begin{array}{r}-0.017 \\
(0.281)\end{array}$ & $\begin{array}{r}0.015 \\
(0.134)\end{array}$ & $\begin{array}{l}0.213^{* * *} \\
(0.006)\end{array}$ & $\begin{array}{l}1.333 * * * \\
(0.002)\end{array}$ & $\begin{array}{r}0.275 \\
(0.143)\end{array}$ \\
\hline Derivatives-trading & $\begin{array}{l}0.104 * * * \\
(0.000)\end{array}$ & $\begin{array}{l}0.062 * * * \\
(0.000)\end{array}$ & $\begin{array}{r}-0.001 \\
(0.924)\end{array}$ & $\begin{array}{l}0.364 * * * \\
(0.000)\end{array}$ & $\begin{array}{l}2.398 * * * \\
(0.000)\end{array}$ & $\begin{array}{l}0.988^{* * * *} \\
(0.000)\end{array}$ \\
\hline Invest. opportunities & $\begin{array}{l}-0.519 * * * \\
(0.000)\end{array}$ & $\begin{array}{l}-0.162 * * \\
(0.031)\end{array}$ & $\begin{array}{c}-0.053 * \\
(0.067)\end{array}$ & $\begin{array}{l}-1.517 * * * \\
(0.001)\end{array}$ & $\begin{array}{l}-9.586^{* * *} \\
(0.000)\end{array}$ & $\begin{array}{l}-3.107 * * * \\
(0.000)\end{array}$ \\
\hline Leverage & $\begin{array}{r}-0.100 \\
(0.774)\end{array}$ & $\begin{array}{r}-0.088 \\
(0.725)\end{array}$ & $\begin{array}{r}0.206 \\
(0.483)\end{array}$ & $\begin{array}{r}-0.799 \\
(0.407)\end{array}$ & $\begin{array}{r}-2.843 \\
(0.659)\end{array}$ & $\begin{array}{l}-4.964 * * \\
(0.022)\end{array}$ \\
\hline Size & $\begin{array}{r}0.000 \\
(0.877)\end{array}$ & $\begin{array}{r}0.000 \\
(0.812)\end{array}$ & $\begin{array}{r}0.000 \\
(0.449)\end{array}$ & $\begin{array}{r}0.000 \\
(0.467)\end{array}$ & $\begin{array}{r}0.000 \\
(0.562)\end{array}$ & $\begin{array}{r}0.000 \\
(0.195)\end{array}$ \\
\hline Diversification & $\begin{array}{l}0.084 * * * \\
(0.000)\end{array}$ & $\begin{array}{r}0.007 \\
(0.610)\end{array}$ & $\begin{array}{r}0.003 \\
(0.831)\end{array}$ & $\begin{array}{l}0.274 * * * \\
(0.000)\end{array}$ & $\begin{array}{l}1.459 * * * \\
(0.001)\end{array}$ & $\begin{array}{l}0.480^{* *} \\
(0.012)\end{array}$ \\
\hline NPLs & $\begin{array}{l}-0.064 \\
(0.584)\end{array}$ & $\begin{array}{l}-0.047 \\
(0.516)\end{array}$ & $\begin{array}{r}0.124 \\
(0.345)\end{array}$ & $\begin{array}{c}-0.478 \\
(0.206)\end{array}$ & $\begin{array}{l}-0.658 \\
(0.756)\end{array}$ & $\begin{array}{r}-0.746 \\
(0.426)\end{array}$ \\
\hline Country factor & $\begin{array}{r}0.080 \\
(0.250)\end{array}$ & $\begin{array}{l}-0.167 * * * \\
(0.000)\end{array}$ & $\begin{array}{l}-0.022 * * * \\
(0.008)\end{array}$ & $\begin{array}{c}0.407^{*} \\
(0.097)\end{array}$ & $\begin{array}{r}1.657 \\
(0.196)\end{array}$ & $\begin{array}{r}-1.184 \\
(0.743)\end{array}$ \\
\hline Year dummy & Yes & Yes & & Yes & Yes & Yes \\
\hline No. Observations & 300 & 134 & 134 & 300 & 300 & 300 \\
\hline Pseudo $R^{2}$ & 0.329 & 0.344 & & 0.440 & 0.166 & 0.075 \\
\hline$R^{2}$ within & & & 0.158 & & & \\
\hline$R^{2}$ between & & & 0.327 & & & \\
\hline$R^{2}$ overall & & & 0.244 & & & \\
\hline
\end{tabular}

For Columns 1-3, the dependent variable is the extent of CDS held for trading at date $t+1$, measured by the notional amount of the CDS used for trading divided by total CDS usage (trading plus hedging). Columns 1, 4, 5 and 6 report 
the results for the full sample, while Columns 2-3 report the results for the subsample containing only CDS users (i.e., only 134 bank-years used CDS). As a robustness check, for Column 4, the dependent variable is equal to 1 if the firm uses CDS for trading purposes, and 0 otherwise. For Column 5, the dependent variable is the notional amount of CDS held for trading at date $t+1$. For Column 6 , the dependent variable is the notional amount of CDS held for trading scaled by total assets at date $t+1$. All variables are defined in Appendix D. The p-values are reported in parentheses. $* * *, * *$ and $*$ show statistical significance at the $1 \%, 5 \%$ and $10 \%$ levels, respectively. 
TABLE 6

Default risk and the use of CDS for hedging purposes

\begin{tabular}{|c|c|c|c|}
\hline & $(1)$ & $(2)$ & (3) \\
\hline Independent variables & $\begin{array}{c}\text { Before the } \\
\text { financial crisis }\end{array}$ & $\begin{array}{c}\text { During the } \\
\text { financial crisis }\end{array}$ & $\begin{array}{c}\text { After the } \\
\text { financial crisis }\end{array}$ \\
\hline CDS-hedging (predicted) & $\begin{array}{l}-0.575^{* * *} \\
(0.008)\end{array}$ & $\begin{array}{l}-0.594^{* *} \\
(0.014)\end{array}$ & $\begin{array}{c}0.313 \\
(0.514)\end{array}$ \\
\hline Salary & $\begin{array}{l}-0.151 \\
(0.729)\end{array}$ & $\begin{array}{r}-0.283 \\
(0.507)\end{array}$ & $\begin{array}{l}-0.780 \\
(0.341)\end{array}$ \\
\hline Bonus & $\begin{array}{r}-0.189 \\
(0.279)\end{array}$ & $\begin{array}{l}-0.188 \\
(0.217)\end{array}$ & $\begin{array}{l}-0.409 \\
(0.148)\end{array}$ \\
\hline Leverage & $\begin{array}{l}5.477 * * \\
(0.011)\end{array}$ & $\begin{array}{l}6.998 * * * \\
(0.006)\end{array}$ & $\begin{array}{l}2.315 \\
(0.647)\end{array}$ \\
\hline Investment opportunities & $\begin{array}{r}-0.569 \\
(0.523)\end{array}$ & $\begin{array}{l}-5.073 * * * \\
(0.000)\end{array}$ & $\begin{array}{l}-1.996 \\
(0.116)\end{array}$ \\
\hline Size & $\begin{array}{r}0.696 \\
(0.044)\end{array}$ & $\begin{array}{l}0.553 * * * \\
(0.000)\end{array}$ & $\begin{array}{c}0.711 \\
(0.257)\end{array}$ \\
\hline Tenure & $\begin{array}{r}0.113 \\
(0.394)\end{array}$ & $\begin{array}{r}0.073 \\
(0.504)\end{array}$ & $\begin{array}{c}0.029 \\
(0.899)\end{array}$ \\
\hline Age & $\begin{array}{r}-0.002 \\
(0.971)\end{array}$ & $\begin{array}{r}-0.024 \\
(0.706)\end{array}$ & $\begin{array}{l}-0.062 \\
(0.568)\end{array}$ \\
\hline Diversification & $\begin{array}{r}-0.073 \\
(0.732)\end{array}$ & $\begin{array}{r}-0.057 \\
(0.775)\end{array}$ & $\begin{array}{l}-0.081 \\
(0.834)\end{array}$ \\
\hline Country Dummy & Yes & Yes & Yes \\
\hline No. Observations & 60 & 180 & 120 \\
\hline Adjusted $\mathrm{R}^{2}$ & 0.386 & 0.443 & 0.340 \\
\hline $\begin{array}{l}\text { The results of two-stage reg, } \\
\text { to default. CDS-hedging is } \\
\text { (predicted) is endogenously } \\
\text { reported here for the sake } \\
\text { respectively. }\end{array}$ & $\begin{array}{l}\text { ent variable is the } \\
\text { ount of CDS hel } \\
\text { options' vega anc } \\
\text { and * show statis }\end{array}$ & $\begin{array}{l}\text { default risk as me } \\
\text { edging scaled by } \\
\text { variables. The firs } \\
\text { nnificance at the }\end{array}$ & $\begin{array}{l}\text { by Merton distance } \\
\text { sets. CDS-hedging } \\
\text { regressions are no } \\
\text { and } 10 \% \text { levels. }\end{array}$ \\
\hline
\end{tabular}


TABLE 7

Robustness check: Default risk and the use of CDS for trading purposes

\begin{tabular}{|c|c|c|c|}
\hline & $(1)$ & (2) & (3) \\
\hline Independent variables & $\begin{array}{c}\text { Before the } \\
\text { financial crisis }\end{array}$ & $\begin{array}{c}\text { During the } \\
\text { financial crisis }\end{array}$ & $\begin{array}{c}\text { After the } \\
\text { financial crisis }\end{array}$ \\
\hline \multirow[t]{2}{*}{ CDS-trading (predicted) } & $-0.247 *$ & $-0.349^{* * *}$ & $-0.416^{*}$ \\
\hline & $(0.058)$ & $(0.005)$ & $(0.060)$ \\
\hline \multirow[t]{2}{*}{ Salary } & -0.136 & 0.146 & -0.410 \\
\hline & $(0.767)$ & $(0.761)$ & $(0.614)$ \\
\hline \multirow[t]{2}{*}{ Bonus } & -0.190 & -0.156 & -0.177 \\
\hline & $(0.309)$ & $(0.335)$ & $(0.506)$ \\
\hline \multirow[t]{2}{*}{ Leverage } & 2.549 & $6.063 * *$ & 5.642 \\
\hline & $(0.194)$ & $(0.010)$ & $(0.197)$ \\
\hline \multirow[t]{2}{*}{ Investment opportunities } & -0.984 & $-5.262 * * *$ & $-2.650 * *$ \\
\hline & $(0.308)$ & $(0.000)$ & $(0.041)$ \\
\hline \multirow[t]{2}{*}{ Size } & $0.743 * *$ & $0.628 * * *$ & $1.420 * *$ \\
\hline & $(0.048)$ & $(0.000)$ & $(0.038)$ \\
\hline \multirow[t]{2}{*}{ Tenure } & 0.101 & 0.000 & 0.028 \\
\hline & $(0.463)$ & $(0.998)$ & $(0.903)$ \\
\hline \multirow[t]{2}{*}{ Age } & 0.031 & -0.029 & -0.014 \\
\hline & $(0.615)$ & $(0.673)$ & $(0.894)$ \\
\hline \multirow[t]{2}{*}{ Diversification } & 0.008 & -0.086 & -0.116 \\
\hline & $(0.971)$ & $(0.691)$ & $(0.763)$ \\
\hline Country Dummy & Yes & Yes & Yes \\
\hline No. Observations & 60 & 180 & 120 \\
\hline Adjusted $\mathrm{R}^{2}$ & 0.336 & 0.352 & 0.248 \\
\hline \multicolumn{4}{|c|}{$\begin{array}{l}\text { The results of two-stage regressions. The dependent variable is the bank's default risk as measured by Merton distance } \\
\text { to default. CDS-trading is the total notional amount of CDS held for trading scaled by total assets. CDS-trading (predicted } \\
\text { is endogenously determined by stock options' vega and other variables. The first-stage regressions are not reported her } \\
\text { for the sake of brevity. } * * *, * * \text { and * show statistical significance at the } 1 \%, 5 \% \text { and } 10 \% \text { levels, respectively. }\end{array}$} \\
\hline
\end{tabular}


Appendix A

\section{A summary of empirical studies on derivatives use and risk-taking incentives induced by stock option compensation}

\begin{tabular}{llc}
\hline Authors & Sample (size \& country) & $\begin{array}{l}\text { Relationship } \\
\text { between stock } \\
\text { options and } \\
\text { derivatives use* }\end{array}$ \\
\hline Tufano (1996) & Negative \\
$\begin{array}{l}\text { Géczy, Minton and Schrand } \\
\text { (1997) }\end{array}$ & 372 US nonfinancial firms & Positive \\
$\begin{array}{l}\text { Nam and Gay (1998) } \\
\text { Knopf, Nam and Thornton (2002) }\end{array}$ & 260 US nonfinancial firms & Positive \\
$\begin{array}{l}\text { Rajgopal and Shevlin (2002) } \\
\text { Rogers (2002) }\end{array}$ & 117 US oil and gas firms & Negative \\
$\begin{array}{l}\text { Adkins, Carter and Simpson } \\
\text { (2007) }\end{array}$ & 252 US financial firms (banks) & Negative \\
$\begin{array}{l}\text { Ertugrul, Sezer and Sirmans } \\
(2008)\end{array}$ & 112 US real estate investment trust firms \\
\begin{tabular}{l} 
Supanvanij and Strauss (2010) \\
\hline
\end{tabular} & 198 US nonfinancial firms & Negative \\
\hline
\end{tabular}

*Note: None of these studies examine the use of CDS. 
Appendix B

A summary of empirical studies on derivatives use and firm risk

\begin{tabular}{|c|c|c|}
\hline Authors & Sample (size \& country) & $\begin{array}{c}\text { Relationship } \\
\text { between } \\
\text { derivatives use } \\
\text { and firm risk }\end{array}$ \\
\hline Guay (1999) & 254 US nonfinancial firms & Negative \\
\hline Allayannis and Ofek (2001) & 378 US nonfinancial firms & Negative \\
\hline Hentschel and Kothari (2001) & $\begin{array}{l}425 \text { US firms from various } \\
\text { industries }\end{array}$ & Insignificant \\
\hline Faulkender (2005) & 133 US chemical firms & Positive \\
\hline Adam and Guettler (2010) & 100 US mutual fund firms & Positive \\
\hline $\begin{array}{l}\text { Bartram, Brown and Conrad } \\
\text { (2011) }\end{array}$ & $\begin{array}{l}6,888 \text { nonfinancial firms from } 47 \\
\text { countries }\end{array}$ & Negative \\
\hline Nijskens and Wagner (2011) & $\begin{array}{l}38 \text { financial firms from various } \\
\text { countries (banks) }\end{array}$ & Positive \\
\hline Fung, Wen and Zhang (2012) & $\begin{array}{l}191 \text { US financial firms } \\
\text { (insurance) }\end{array}$ & Positive \\
\hline
\end{tabular}




\section{Appendix C}

\section{Calculating the risk-taking incentives of stock options (vega)}

The following equation is adopted from Core and Guay (2002):

$$
\begin{aligned}
& \text { Vega }=\frac{\partial v a l u e}{\partial \sigma} \times 0.01 \\
& =e^{-d T} N^{\prime}(Z) S \sqrt{T} \times 0.01 \\
& \text { Where } Z=\frac{\ln (S / X)+\left(r f-d+0.5 \sigma^{2}\right) T}{\sigma \sqrt{T}} \\
& N^{\prime}=\text { normal density function } \\
& X=\text { the exercise price of the option } \\
& r f=\text { the risk-free interest rate } \\
& d \quad=\quad \text { expected dividend yield over the life of the option }
\end{aligned}
$$$$
S=\text { the price of the underlying stock at the valuation date }
$$$$
\sigma=\text { the expected stock return volatility }
$$$$
T=\text { time to expiration date }
$$

\section{Merton distance to default calculation}

$$
\begin{array}{ll}
D D_{t}= & \multicolumn{1}{c}{\ln \left(V_{A ; t} / L_{t}\right)+\left(r-0.5 \sigma_{A ; t}^{2}\right) T} \\
\sigma_{A, t} & \sigma_{E, t} \sqrt{T} V_{E, t} /\left(V_{E, t}+L_{t}\right) \\
V_{A, t} & \text { the market value of assets } \\
L_{t} & \text { the book value of total liabilities } \\
r & \text { the risk-free rate } \\
\sigma_{A, t} & \text { the annualised asset volatility at t } \\
T & \text { the time to maturity } \\
\sigma_{E} & \text { the historical volatility of equity }
\end{array}
$$


APPENDIX D

Variables and definitions

\begin{tabular}{|c|c|}
\hline Variable & Definition \\
\hline Salary & CEO's annual base salary. \\
\hline Bonus & CEO's cash bonuses. \\
\hline Stock grants & The value of stock grants held by the CEO at the end of year. \\
\hline CEO vega & $\begin{array}{l}\text { The pay-risk sensitivity: the change in the dollar value of CEO } \\
\text { wealth for a } 0.01 \text { change in stock return volatility, measured by } \\
\text { partial derivatives of the Black-Scholes value of options with respect } \\
\text { to stock return volatility. }\end{array}$ \\
\hline Ownership & The percentage of the bank's ordinary shares owned by the CEO. \\
\hline Age & The age of the bank's CEO. \\
\hline Tenure & The number of years the CEO has served the bank. \\
\hline CDS-trading & $\begin{array}{l}\text { The notional amount of CDS held for trading purposes. This is } \\
\text { scaled by either total CDS held or total assets. }\end{array}$ \\
\hline CDS-hedging & $\begin{array}{l}\text { The notional amount of CDS held for hedging purposes. This is } \\
\text { scaled by either total CDS held or total assets. }\end{array}$ \\
\hline Derivatives-hedging & Total notional amount of derivative contracts for hedging purposes. \\
\hline Derivatives-trading & Total notional amount of derivative contracts for trading purposes. \\
\hline Investment opportunities & Market-to-book value of assets. \\
\hline Leverage & Book value of debt/book value of total assets. \\
\hline Default risk & $\begin{array}{l}\text { The number of standard deviations that the market value of bank } \\
\text { assets is above default point. Default is where the market value of } \\
\text { assets is less than the book value of total liabilities. }\end{array}$ \\
\hline Size & Total revenue. \\
\hline Diversification & $\begin{array}{l}\text { The number of geographical segments covered by a bank's } \\
\text { operation. }\end{array}$ \\
\hline NPLs & $\begin{array}{l}\text { Based on the ratios of non-performing loans for banks in each } \\
\text { country (value equals } 1 \text { if the NPL ratio is lower than the average } \\
\text { NPL ratio of European banks, and } 0 \text { otherwise). }\end{array}$ \\
\hline
\end{tabular}

